УДК 338.482:728.51

DOI: https://doi.org/10.37320/2415-3583/9.16

Джгуташвілі Н.М.

аспірантка кафедри маркетингу і комерційної діяльності, Харківський державний університет харчування та торгівлі;

викладач,

Київький державний коледж туризму та готельного господарства

\title{
ВПЛИВ В'ЇЗНОГО ТУРИСТИЧНОГО ПОТОКУ НА РОЗВИТОК ГОТЕЛЬНОГО СЕРВІСУ В УКРАЇНІ
}

У статті проаналізовано сучасні тенденції в 'їзих потоків та установлено, щцо має місце їх зменшення, унаслідок чого падає попит іноземиів на готельні послуги, більшою частиною яких користуються вітчизняні споживачі. Виявлено, що об 'єктивними причинами зниження в 'їзнх потоків є несприятливий безпековий імідж країни, а також низький рівень туристичної конкурентоспроможності Украӥни, тому вітчизняна готельна індустрія слабо реалізує свій потениіал. Зазначено необхідність застосування світового досвіду та практики сервісного менеджменту, що даст змогу підвищити привабливість готелів для гостей. Запропоновано здійснювати управління сервісом у готельній індустрї на принциипах ланцңюжка споживчої цінності та використовувати при ц̧ьому колесо сервісного продукту підприємств готельної індустрії, до якого включено такі складники, як матеріальнотехнічна база, персонал, процес, принципи та правила гостинності.

Ключові слова: готельна індустрія, сервісний продукт, туризм, туристична конкурентоспроможність, колесо сервісного продукту.

Постановка проблеми. За даними Всесвітньої організації туризму (UNWTO), динамічний розвиток туризму визнано глобальною силою економічного зростання. За 2018 р. міжнародні туристичні потоки зросли на 5\%, випередивши товарний експорт, а прибуток від експорту туристичних послуг збільшився до 1,7 трлн дол., що на 4\% перевищує показник 2017 р. [18]. У цілому темпи зростання прибутків та надходжень від туризму випереджають темпи розвитку світової економіки: 4\% у туризмі проти 3,6\% зростання світового ВВП [18].

В Україні за тим же звітом (UNWTO) іноземні відвідувачі у 2018 р. витратили за безготівковими розрахунками 1,2 млрд дол., що на 400 млн дол. більше порівняно 32017 р. [18]. Проте витрати українців у подорожах за кордоном у декілька разів вищі, вони сягають майже $8 \%$ вітчизняного ВВП. За таких умов виїзний туризм значно перевищує в'їзний як за кількістю подорожуючих, так i за обсягами витрат, при цьому частка вітчизняної туристичної індустрії становить менше $2 \%$ ВВП, що є значно меншим показником, аніж у середньому у світі. За такої ситуації посилюються загрози функціонуванню та розвитку сфер вітчизняної індустрії гостинності.

Будучи невід'ємним та вагомим складником туризму, готельна індустрія набуває все більшого соціально-економічного значення, вона $є$ ключовим складником туристичного продукту, оскільки рівень сервісу в закладах готельного господарства - один із вагомих чинників задоволеності подорожуючих. Сучасний розвиток готельної мережі в Україні відстає від європейських країн. За даними Cushman \& Wakefield, у Києві забезпеченість номерним фондом найнижча серед столиць держав Центральної і Східної Свропи - 3,5 номера на 1 тис мешканців, що в два рази менше середнього європейського показника [4]. Із цього можна констатувати, що готельна індустрія України має потенціал для зростання. Але потенціал наявної на даному етапі мережі слабо реалізовується, що значною мірою пов'язано з незначними потоками іноземців до України, у тому числі туристів.

У цілому туристична та готельна сфери взаємопов'язані, оскільки саме в'їзні та внутрішні туристичні потоки забезпечують попит на готельні послуги, але, своєю чергою, якість сервісу в готелі впливає на його формування та вибір конкретного закладу для розміщення, тому першочерговим завданням закладів готельного господарства $€$ підвищення якості обслуговування та сервісу.

Аналіз останніх досліджень і публікацій. Місце України на міжнародному ринку туристичних послуг розглянуто у працях вітчизняних учених, серед яких - Л. Бабіна, Н. Бунтова, Н. Марценюк, А. Мурай, С. Полковниченко, Є. Смирнов, О. Смирнова, Н. Степаненко [1; $2 ; 6$; 12-14]. Авторами визначено проблеми туризму в Україні, проаналізовано чинники туристичної конкурентоспроможності та обгрунтовано перспективи його розвитку, серед яких одним із напрямів визначено необхідність удосконалення готельної індустрії. У наукових працях О. Свтушенко, Ю. Лелі, Н. Онищук, В. Папп, П. Подлепіна, А. Ткаченко, I. Чуєнко [10-11; 15] та ін. доведено взаємний вплив готельного та туристичного господарства, здійснено аналіз його стану та тенденцій в Україні, визначено недоліки та перспективи. Авторами зазначається, що у перспективі саме готельний бізнес стане про- 
відним чинником активізації туризму, інтеграції держави у світові структури міжнародного співробітництва [15], а для цього пріоритетними завданнями визначено вдосконалення системи якості надання послуг, формування клієнт-орієнтованого сервісу, оновлення матеріально-технічної бази, імплементація міжнародних стандартів обслуговування, використання інноваційних форм організації готельного бізнесу [13]. Ураховуючи, що готельне господарство відрізняється від інших сфер економічної діяльності більш високими рівнем динамічності, це зумовлює необхідність науково обгрунтованих підходів до формування готельного сервісу 3 акцентом на вимогливість та очікування клієнтів.

Мета статті полягає у визначенні сучасних тенденцій та впливу в'їзних туристичних потоків на розвиток готельної індустрії України.

Виклад основного матеріалу. Світовий туристичний ринок розвивається нерівномірно, внаслідок чого формуються регіональні особливості розвитку туристичної інфраструктури та конкуренції на ньому. За даними UNWTO [18], найбільший потік туристів у 2018 р. у світових масштабах спостерігався в Європі - понад 710 млн осіб, що принесло дохід у 570 трлн дол. (рис. 1), приріст відповідно до 2017 р. за обома показниками становив 5\%. У два рази менше, а саме близько 350 млн осіб, подорожували до країн Азії та Океанії, дохід становив 435 трлн дол, приріст показників - по 7\% відповідно. На 7\% у 2018 р. збільшився потік туристів і до Африки, яку відвідали 216 млн туристів, проте дохід збільшився лише на 2\%. Найменше туристи відвідують країни Аме- рики та Середнього Сходу, потік туристів до них становить 60-67 млн осіб.

Для розвитку готельної індустрії в Україні важливим $\epsilon$ стимулювання зростання в’їзних туристичних потоків. Цьому сприяло відкриття лоукостів (Air Malta, Buta Airways, Brussels Airlines, Ernest Airlines, SWISS), унаслідок чого пасажиропотік аеропортів «Київ» і «Бориспіль» в I кварталі 2019 р. зріс до 638 тис $(+44,3 \%)$ і 2,65 млн (+ 15,2\%) осіб відповідно [4], що зумовило підвищену зацікавленість іноземців Києвом як економічним і туристичним центром, який до того ж $є$ найдешевшою столицею у Європі.

Графік на рис. 1 указує на пряму залежність кількості іноземних осіб, що перебували у колективних засобах розміщення в Україні, від динаміки кількості іноземців, які в'їджали до України. За розрахунками, проведеними на основі статистичних даних Державної служби статистики [5], у структурі осіб, що перебували у колективних засобах розміщення (КЗР), суттєво переважає частка вітчизняних гостей, причому з 2015 р. їх кількість щороку зростає, зокрема у 2018 р. на 4,3\% порівняно з 2017 p.

Для стимулювання в'їних потоків необхідне підвищення туристичної конкурентоспроможності України. На підтвердження цього, за даними World Economic Forum [16; 17], у міжнародному рейтингу туристичної конкурентоспроможності Україна у 2018 р. серед 140 країн посідала 78-е місце 3 індексом 3,7, що є певним поліпшенням порівняно 3 85-м місцем у рейтингу 2011 р. (табл. 1).

Відповідно до наведених у табл. 1 даних, вузьким місцем вітчизняної туристичної кон-

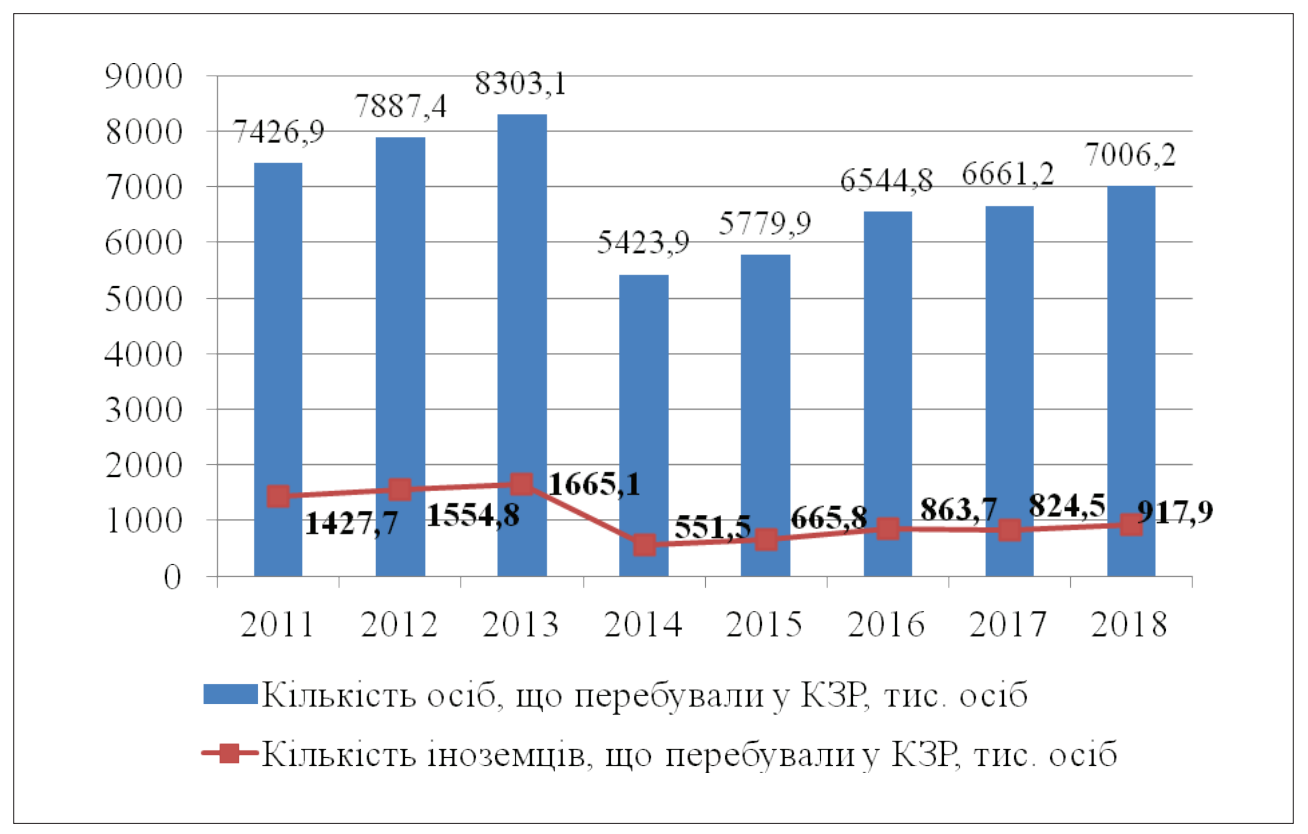

Рисунок 1 - Динаміка кількості осіб, що перебували у колективних засобах розміщення в Україні у 2011-2018 pp. 
Таблиця 1- Показники туристичної конкурентоспроможності України у світовому рейтингу в 2017-2018 pp.

\begin{tabular}{|l|c|c|c|c|}
\hline \multicolumn{1}{|c|}{ Показник } & $\mathbf{2 0 1 1}$ & $\mathbf{2 0 1 7}$ & $\mathbf{2 0 1 8}$ & $\begin{array}{c}\text { 3міна 2017 } \\
\text { до 2018 +/- }\end{array}$ \\
\hline Індекс туристичної конкурентоспроможності & 3,83 & 3,5 & 3,7 & 0,2 \\
\hline Ранг у рейтингу & 85 & 88 & 78 & +10 \\
\hline Складники індексу: & & & & \\
\hline Бізнес-середовище & 3,5 & 3,7 & 4,1 & 0,4 \\
\hline Рівень безпеки & 4,5 & 3,5 & 4,8 & 1,3 \\
\hline Охорона здоров'я та гігієна & 6,5 & 6,6 & 6,5 & $-0,1$ \\
\hline Людські ресурси та ринок праці & 4,9 & 4,9 & 4,8 & $-0,1$ \\
\hline Готовність до інформаційно-комунікаційних технологій & - & 4,2 & 4,5 & 0,3 \\
\hline Пріоритизація сфери & 4,1 & 4,3 & 4,3 & 0 \\
\hline Міжнародна відкритість & - & 2,96 & 3,7 & 0,74 \\
\hline Цінова конкурентоспроможність & 4,0 & 5,2 & 5,9 & 0,7 \\
\hline Екологічна стійкість & - & 3,9 & 4,1 & 0,2 \\
\hline Інфраструктура повітряного транспорту & 2,6 & 2,4 & 2,6 & 0,2 \\
\hline Інфраструктура наземного та водного транспорту & 3,4 & 3 & 3,9 & 0,9 \\
\hline Туристична інфраструктура: & 3,2 & 4 & 3,2 & $-0,8$ \\
\hline наявність великих компаній із прокату автомобілів; & & 5 & & \\
готельні номери (кількість на 100 осіб ); & & 0,2 & & \\
якість туристичної інфраструктури; & & 3,9 & & \\
\hline кількість банкоматів (кількість на 1 тис дорослого населення) & & 94,6 & & $-0,1$ \\
\hline Природні ресурси & 2,3 & 2,3 & 2,2 & $-0,2$ \\
\hline Культурні ресурси та ділові поїздки & 1,9 & 2,1 & 1,9 & \\
\hline
\end{tabular}

Джерело: складено автором за даними WEF [16; 17]

курентоспроможності $є$ складник «туристична інфраструктура», що демонструє зниження на 0,8 пункти. Серед основних показників туристичної інфраструктури найгірші позиції спостерігаються за кількістю готельних номерів - 103-є місце та за якістю туристичної інфраструктури 107-е [16; 17]. Для поліпшення ситуації пріоритетними завданнями $є$ розвиток готельної мережі та покращення сервісу в готелях.

В Україні відзначаються такі регіональні особливості розвитку готельної індустрії. Сформувалися декілька потужних центрів, які відрізняються особливостями туризму, що зумовлює спрямованість готельної індустрії: готелі в західних і південних областях орієнтовані на рекреаційний туризм; у столиці та великих містах-мільйонниках (Харків, Дніпро, Львів) - на корпоративних туристів, у зв'язку з чим вони відрізняються й пропонованими сервісними продуктами.

Ураховуючи більш високі темпи розвитку готельної індустрії у м. Києві, однією 3 національних особливостей $є$ концентрація більшості готелів України в столиці, зокрема за категорією п'яти зірок. Даний регіональний ринок стрімко розвивається: за даними Cushman \& Wakefield, протягом 2016-2020 pр. номерний фонд готелів столиці збільшився з 10117 номерів до 11451 , приріст становив 13\% [4]. Проте показник забезпеченості номерним фондом у розрахунку на 1 тис жителів залишається найнижчим серед європейських столиць: Київ - 3,5 номери, Софія 5,2, Прага - 27,3 номери [4]. У 2019 р. у структурі готелів у Києві переважали тризіркові та чотиризіркові готелі, їх частка становила $38 \%$ та $34 \%$ відповідно, причому кількість чотиризіркових готелів має тенденцію до щорічного збільшення.

Аналізуючи середню вартість номерного фонду у м. Києві за даними Colliers International за перший квартал 2019 р., установлено досить високий рівень цін: середня вартість номера у п'ятизірковому готелі - 369 євро, у чотиризірковому - 147 євро, у тризірковому - 69 євро [4]. Середній показник завантаженості столичних готелів коливається на рівні 50-60\%, проте найменша завантаженість має місце у п'ятизіркових готелях, рівень цін в яких набагато вище, ніж у столицях більшості європейських країн, і сягає рівня цін віденських готелів, тоді як за рівнем сервісного продукту вітчизняні готелі, включаючи столичні, значно поступаються європейським. Це свідчить про необхідність поліпшення якісних показників розвитку мережі й розвитку закладів із більш високим рівнем сервісного продукту. На тлі нестачі якісних готелів сегменту budget-midscale, попит на які є найвищим, відзначається надлишок готелів найвищого цінового сегменту upscale, upper upscale i luxury.

Після анексії АР Крим новий етап розвитку відбувся у південних областях України: Одеській, Херсонській, Миколаївській, Запорізькій, що пов'язано зі стрімким зростанням потоків турис- 
тів. За даними мерії Одеси, у 2018 р. ії відвідали понад 3,2 млн туристів [8], що на 700 тис, або на $22 \%$, перевищує показник 2017 р. Проте потенціал готельної індустрії в південних областях слабко розвинутий. В Одесі функціонує лише 65 готелів із номерним фондом 4 тис місць, які, звісно, не спроможні обслуговувати 3,2 млн туристів, при цьому лише один готель має п'ять зірок (належить до міжнародного готельного оператора AccorHotels). Отже, спостерігається нестача готелів високого рівня, і конкуренція у цьому сегменті майже відсутня, а готелям сегментів budget i midscale конкуренцію становлять альтернативні варіанти розміщення: апартаменти, орендовані кімнати та квартири. Однією з проблем готелів у Південному регіоні $є$ вагомий вплив чинника сезонності, що вимагає спрямування зусиль менеджменту на формування особливої пропозиції сервісного продукту у період падіння попиту.

Статистичні дані щодо туризму в Україні [3; 5] вказують на пряму залежність кількості іноземних осіб, що перебували у колективних засобах розміщення в Україні, від динаміки кількості іноземців, які в'їжджали до України. За даними [5], встановлено, що лише 6-7\% іноземних громадян, які в'їжджали в Україну в 2010-2017 рр., перебували у колективних засобах розміщення (КЗР), а в 2013 р. ще менше, лише 2,2\%. Це пов'язано зі значним транзитним потоком іноземних осіб через територію України. На рис. 2 наведено динаміку кількості осіб, що перебували в колективних засо- бах розміщення, та встановлено, що з 2015 р. спостерігається щорічне збільшення кількості осіб, які скористалися їхніми послугами. Причому більшу їх частину становлять українські гості, a кількість та частка іноземних має негативну тенденцію до скорочення.

Перебуваючи в Україні, переважна більшість іноземних громадян проживає у друзів чи знайомих або для тимчасового розміщення вибирають альтернативні варіанти: орендують квартири (кімнати), приватні будинки або кімнати в них, кімнати в гестхаусах. Тим самим попит на послуги закладів готельного господарства в Україні з боку іноземних громадян $є$ низьким, що зумовлює необхідність його стимулювання, а також підвищення привабливості готелів для них.

Вибір місця для тимчасового розміщення під час перебування в іноземній країні певною мірою залежить від мети поїздки. За даними UNWTO, серед мотивів туристичних подорожей у світі переважають відпустка, дозвілля, відпочинок, канікули, на їхню частку припадає 56\%, причому порівняно з 2000 р. вона зросла на 6\% [18]. Вимоги цих туристів до сервісу готелів полягають у максимізації комфорту, створенні сприятливої атмосфери для спілкування, розваг, у тому числі для дітей, забезпеченні відповідними послугами. 3 метою відвідування друзів та родичів, для зміцнення здоров'я, з релігійними мотивами подорожує $27 \%$ туристів, із них лише незначна частина користується готелями. Для подорожуючих is

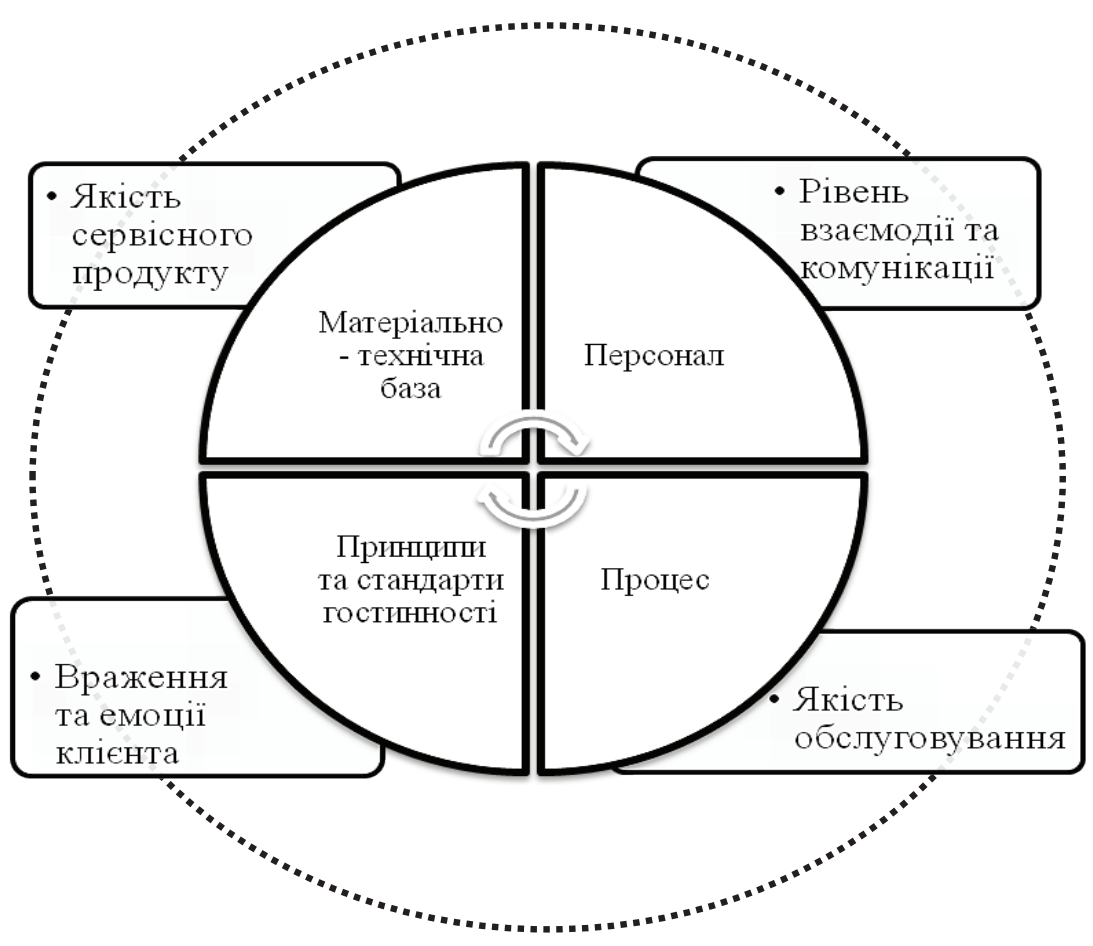

Рисунок 2 - Колесо сервісного продукту підприємств готельної індустрії 
метою оздоровлення пріоритетом вибору готелю $€$ перелік та якість саме оздоровчих послуг та харчування. Подорожуючи за релігійними мотивами, туристи, як правило, менш вибагливі до комфорту та переліку послуг у готелі. Бізнес та професійні подорожі займають 13\%. У кожної категорії приїжджих свої вимоги, потреби, очікування щодо сервісного продукту, тому необхідним є їх вивчення та врахування для переходу до управління діяльністю готелю за принципом клієнт-орієнтованості. Із цією метою актуалізується пошук адекватних методів сегментації ринку і диференціації сервісного продукту готелів залежно від особливостей цільової аудиторії.

Специфіка розподілу іноземних туристичних потоків за мотивами подорожі в Україну характеризується переважанням транзиту, приватних поїздок. Із метою туризму Україну відвідали лише 38 тис осіб, або 0,27\% від чисельності іноземних громадян, які в’їжджали в Україну в 2017 р. Зі службовою, діловою, дипломатичною метою Україну відвідали майже 89 тис осіб, або 0,63\% в'їзного потоку іноземних громадян; із метою культурного та спортивного обміну, релігійних мотивів - 348,8 тис осіб, що становило 2,45\% від чисельності іноземних громадян, які в’їхали в Україну. За таких умов попит на послуги готелів $€$ значно нижчим за потенційну місткість ринку готельних послуг, проте іноземних туристів не задовольняє рівень сервісу у вітчизняних готелях. Наведені тенденції значно уповільнюють розвиток готельної індустрії. Тим самим колективними засобами розміщення втрачається такий важливий сегмент, як іноземні гості, який є більш привабливим із погляду доходності та обсягів споживання готельних послуг і сприяє більшому надходженню грошових ресурсів. Саме іноземці віддають перевагу більш комфортним номерам, а отже, більш дорогим, а під час перебування споживають більшу кількість додаткових послуг, що збільшує джерела доходів готелів.

На основі даних Державної служби статистики [3] визначено, що серед цих категорій потенційних споживачів в Україні потоки туристів скоротилися за досліджуваний період з 1,08 млн осіб до 38 тис, тобто на 96,4\%: потоки іноземних громадян, які приїжджали в Україну в службову, ділову, дипломатичну поїздку - на 87,2\%, скоротилися й потоки іноземних громадян, які приїжджали в Україну з метою задоволення культурних, спортивних, релігійних потреб, - на 28\%.

Об’єктивною причиною зниження в’“їних потоків до України є непривабливий імідж країни, зумовлений військово-політичним конфліктом на Сході та анексією АР Крим, унаслідок чого Україну, згідно з рейтингом Світового економічного форуму 2017 р. [16; 17], віднесено до ТОП-10 найнебезпечніших країн для туризму i подорожей.
Хоча в 2018 р. позиція України поліпшилася (зі 127-го місця піднялася на 107-е), деякі посольства та консульства країн світу продовжують поширювати інформацію щодо ризиків та небезпеки знаходження в Україні. Крім того, не задовольняє також іноземних туристів наявна туристична інфраструктура, зокрема низьким вважається рівень обслуговування у закладах готельного господарства, що також певним чином погіршує привабливість України і знижує їі туристичну конкурентоспроможність.

Із метою створення привабливості готелів для гостей необхідно застосовувати світовий досвід та практику сервісного менеджменту. Управління сервісом у готельній індустрії нами запропоновано здійснювати на принципах ланцюжка споживчої цінності. На рис. 2 подано схематичне зображення колеса сервісного продукту підприємств готельної індустрії.

Сервісний продукт включає матеріально-технічну базу, персонал відповідної кваліфікації, організацію технологічних процесів відповідно до принципів і правил гостинності, які в сукупності утворюють більш високу споживчу цінність і здатні формувати враження у клієнтів, впливати на їх прихильність.

Застосування даного підходу дає змогу виявити проблемні місця в управлінні сервісом у готельній індустрії. Найбільш складною проблемою вітчизняних готелів $є$ невідповідність рівня сервісу світовим стандартам, що певним чином пов' язано із застарілістю матеріально-технічної бази та низькою кваліфікацією персоналу. За даними Державної служби статистики України [7], зношеність основних засобів підприємств тимчасового розміщування й організації харчування $\epsilon$ високою і коливається на рівні 32-42\%. Причому якщо в 2011 р. вона зменшилася iз 43,4\% до $32,4 \%$, що було пов'язано з оновленням матеріально-технічної бази у зв'язку з підготовкою до Свро-2012, то з 2012 р. ступінь зношеності основних засобів має тенденцію до зростання. У цілому за досліджуваний період даний показник збільшився на 10\%, і в 2016-2018 рр. зношеність основних засобів перевищувала $40 \%$.

За таких умов вітчизняні готелі значно поступаються за рівнем сервісного продукту європейським та світовим закладам, що зумовлює необхідність спрямування зусиль не лише на пошук інвестицій, а й на розроблення інструментарію управління клієнт-орієнтованістю сервісу.

Висновки. Під впливом глобалізаційних процесів відбувається стрімкий розвиток туризму в усіх регіонах світу, що зумовлює перспективи для сфер послуг, які обслуговують туристів, у тому числі сфери гостинності. Спираючись на результати проведеного аналізу, можна констатувати таке. 
1. В Україні склалися умови, що стимулюють зростання в 'їзних туристичних потоків: відкриття лоукостів, відносна економічна доступність для перебування іноземців. Проте несприятливий безпековий імідж країни, а також низький рівень туристичної конкурентоспроможності значною мірою зумовлені нестачею кількості готелів із достатнім рівнем сервісу за прийнятною ціною.

2. Для поліпшення туристичної інфраструктури і підвищення туристичної конкурентоспроможності України на світовому ринку у сфері готельної індустрії необхідно розвивати сучасні формати та розширювати мережу закладів тимчасового розміщування, особливо сегменту budgetmidscale, а також спрямовувати зусилля на підвищення споживчої цінності сервісного продукту. Пріоритетом у цьому напрямі є систематичний моніторинг та відстеження світових трендів у готельній індустрії, основні 3 яких пов'язані 3 можливостями, які надає стрімкий розвиток інформаційно-комунікаційних та цифрових технологій, а також своєчасне виявлення зміни потреб і очікувань споживачів. Ураховуючи принципи сталого розвитку, створенню сприятливих довгострокових перспектив для закладів тимчасового розміщування, у тому числі готелів, сприя- тиме підвищення їх соціальної відповідальності, що дасть змогу сформувати їм позитивний імідж та поліпшити привабливість для споживачів.

3. Для підвищення конкурентоспроможності операторів вітчизняного ринку готельних послуг постає необхідність управління клієнт-орієнтованістю сервісу готелю. У цьому напрямі першочерговим завданням $\epsilon$ інтеграція світового досвіду та вітчизняної практики на принципах сервісного менеджменту та запропонованого колеса сервісного продукту готелю, яке включає матеріальнотехнічну базу, персонал, процес, принципи та правила гостинності. Запропонований підхід дає змогу поєднати стандарти якості надання послуг 3 очікуваннями та враженнями клієнта готелю. Виявлені проблеми стосуються підвищення комфортності умов проживання; оптимізації цінової політики щодо забезпечення оптимального співвідношення «ціна/якість»; упровадження високих стандартів гостинності, що значною мірою забезпечується професіоналізмом та рівнем кваліфікації персоналу.

Одержані результати можуть бути використані в подальших дослідженнях для аналізу та розроблення системи управління клієнт-орієнтованістю сервісу операторів готельної індустрії.

\section{Список використаних джерел:}

1. Бабіна Н.І. Аналіз рейтингу конкурентоспроможності країн у галузі міжнародного туризму. Глобальні та національні проблеми економіки. 2015. Вип. 3. С. 33-38. URL : http://global-national.in.ua/vipusk-3-2015/326-babina-n-ianalizrejtingu-konkurentospromozhnosti-krajin-u-galuzi-mizhnarodnogo-turizmu (дата звернення: 12.11.2019).

2. Бунтова Н.В. Потенціал України на міжнародному ринку туристичних послуг. Науковий вісник Херсонського державного університету. Серія «Економічні науки». 2016. Вип. 17. Ч. 2. С. 21-24.

3. В'їзд іноземних громадян в Україну за країнами, з яких вони прибули, у 2018 році. URL : http://www.ukrstat.gov.ua/ operativ/operativ2013/ tyr/xls/vig2017_u.zip (дата звернення: 12.11.2019).

4. Гостиничный бизнес в Украине: стоит ли инвестировать сегодня? Cushman \& Wakefield. URL : https:// cushmanwakefield.com.ua/ru/analytics-page (дата звернення: 12.11.2019).

5. Колективні засоби розміщування (2011-2018). URL : http://www.ukrstat.gov.ua/operativ/operativ2013/tur/zr_u.xls (дата звернення: 12.11.2019).

6. Марценюк Л.В. Проблеми та перспективи розвитку туризму в Україні. Економічний вісник Національного гірничого університету. 2015. № 3. С. 76-82.

7. Наявність і стан основних засобів за видами економічної діяльності / Державна служба статистики України. URL : http://www.ukrstat.gov.ua/operativ/operativ2013/ibd/nsoz/xls/nsoz16 u.zip (дата звернення: 12.11.2019).

8. Огляд ринку готельної нерухомості / Colliers International. URL : https://www2.colliers.com/uk-UA/Research\# sort=date\%20descending (дата звернення: 12.11.2019).

9. Онищук Н.В. Розвиток індустрії гостинності в Україні та світі. Східна Європа: економіка, бізнес та управління. 2019. Вип. 4(21). С. 297-304.

10. Папп В.В. Роль готельного господарства у розвитку туризму в регіоні. Науковий вісник Ужгородського університету. Серія «Економіка». 2015. Вип. 2. С. 207-212.

11. Подлепіна П.О., Свтушенко О.В., Чуєнко І.А. Сучасний стан та перспективи розвитку готельного господарства в Харківській області. Вісник Харківського національного університету імені В.Н. Каразіна. Серія «Міжнародні відносини. Економіка. Країнознавство. Туризм». 2017. Вип. 6. С. 191-197.

12. Полковниченко С.О., Мурай А.О. Оцінка конкурентоспроможності України на європейському ринку туристичних послуг. URL : http://www.economy.nayka.com.ua/pdf/12_2018/114.pdf (дата звернення: 12.11.2019).

13. Смирнов Є.В., Смирнова О.П. Стратегічні імперативи розвитку туристичної галузі України. Економіка та держава. 2016. № 8. С. 28-34.

14. Степаненко Н.О. Розвиток туристичної діяльності України в умовах євроінтеграції. Міжнародні відносини. Серія «Економічні науки». 2017. № 10. URL : http://journals.iir.kiev.ua/index.php/ec_n/article/view/3107 (дата звернення: 12.11.2019).

15. Ткаченко А.М., Лелі Ю.Г. Проблеми та перспективи розвитку готельного бізнесу в умовах сьогодення. Причорноморські економічні студії. 2016. Вип. 12-1. С. 185-188. 
16. The Travel \& Tourism Competitiveness Report 2019. URL : http://www3.weforum.org/docs/WEF_TTCR_2019.pdf (дата звернення: 12.11.2019).

17. The Travel \& Tourism Competitiveness Report 2017. URL : http://reports.weforum.org/travel-and-tourismcompetitiveness-report-2017/ (дата звернення: 16.11.2019).

18. UNWTO Tourism Highlights, 2018 Edition. URL : https://www.e-unwto.org/doi/pdf/10.18111/9789284419876 (дата звернення: 16.11.2019).

\section{References:}

1. Babina, N.I. (2015) Analiz reitynhu konkurentospromozhnosti krain u haluzi mizhnarodnoho turyzmu [Analysis of rating of countries competitiveness in international tourism], Global ni ta nacional ni problemy ekonomiky, Vol.3, pp.33-38, available at: http://global-national.in.ua/vipusk-3-2015/326-babina-n-ianaliz-rejtingu-konkurentospromozhnosti-krajin-ugaluzi-mizhnarodnogo-turizmu (accessed 12 November 2019).

2. Buntova N.V. (2016) Potentsial Ukrainy na mizhnarodnomu rynku turystychnykh posluh [The potential of ukraine in the international tourist market], Bulletin of Kherson State University. Series Economic Sciences, vol. 17. no 2, pp. 21-24.

3. Derzhavna sluzhba statystyky Ukrainy (2018) Vizd inozemnykh hromadian v Ukrainu za krainamy, z yakykh vony prybuly, $u 2018$ rotsi [Foreign nationals enter Ukraine by country of origin in 2018], Kyiv: Informatsiino-analitychne ahentstvo, available at: http://www.ukrstat.gov.ua/operativ/operativ 2013/tyr/xls/vig2017 u.zip (accessed 12 November 2019).

4. Gostinichnyy biznes v Ukraine: stoit li investirovat segodnya? [Hospitality in Ukraine: is it worth investing today?], available at: Cushman \& Wakefield. URL. https://cushmanwakefield.com.ua/ru/analytics-page. (accessed 12 November 2019).

5. Derzhavna sluzhba statystyky Ukrainy (2018) Kolektyvni zasoby rozmishchuvannia (2011-2018) [Collective placement facilities], Kyiv: Informatsiino-analitychne ahentstvo, available at: http://www.ukrstat.gov.ua/ operativ/operativ2013/tur/zr_u. xls (accessed 12 November 2019).

6. Martseniuk L.V. (2015) Problemy ta perspektyvy rozvytku turyzmu v Ukraini [Problems and prospects of tourism development in Ukraine], Bulletin of the National Mining University, no 3, pp. 76-82.

7. Derzhavna sluzhba statystyky Ukrainy (2018) Naiavnist $i$ stan osnovnykh zasobiv za vydamy ekonomichnoi diialnosti [Presence and condition of fixed assets by types of economic activity], Kyiv: Informatsiino-analitychne ahentstvo, available at: http://www.ukrstat.gov.ua/operativ/operativ2013/ibd/nsoz/ xls /nsoz16_u.zip (accessed 12 November 2019).

8. Onyshchuk N.V. (2019) Rozvytok industrii hostynnosti v Ukraini ta sviti [Development of industry of hospitality is in Ukraine and world], Eastern Europe: Economics, Business and Management, vol. 4 (21), pp. 297-304.

9. Ohliad rynku hotelnoi nerukhomosti [Overview of the hotel real estate market], available at: https:/www2.colliers.com/ uk-UA/Research\#sort=date\%20descending (accessed 12 November 2019).

10. Papp V. V. (2015) Rol hotelnoho hospodarstva u rozvytku turyzmu v rehioni [The role of hotel management in the development of tourism in the region], Scientific Bulletin of Uzhgorod University. Series: Economics, vol. 2, pp. $207-212$.

11. Podlepina P. O., Yevtushenko O. V., Chuienko I. A. Suchasnyi stan ta perspektyvy rozvytku hotelnoho hospodarstva v Kharkivskii oblasti [Current state and prospects of the hotel industry development in Kharkiv region], Bulletin of the Karazin Kharkiv National University. Series: International Relations. Economy. Country Studies. Tourism, vol. 6, pp. 191-197

12. Polkovnychenko S. O., Murai A. O. (2018) Otsinka konkurentospromozhnosti Ukrainy na yevropeiskomu rynku turystychnykh posluh [Assessment of ukraine's competitiveness in the european market of tourist services], An efficient economy, no 12. available at: http://www.economy.nayka.com.ua/?op=1\&z=6789 (accessed 12 November 2019).

13. Smyrnov, I., Smyrnova, O. (2016) Strategic imperatives of development tourism in Ukraine [Strategic imperatives of development tourism in Ukraine], Economy and the state, vol. 8, pp.28-34.

14. Stepanenko N.O. (2017) Rozvytok turystychnoi diialnosti Ukrainy v umovakh yevrointehratsii [Development of tourism activity of Ukraine in the conditions of European integration], International relations. Economic Sciences Series. vol. 10, available at: http://journals.iir.kiev.ua/index. php/ec_n/article/view/3107 (accessed 12 November 2019).

15. Tkachenko A.M, Lely Yu.G. (2016) Problemy ta perspektyvy rozvytku hotelnoho biznesu v umovakh sohodennia [Problems and prospects of development of hotel business in present conditions], Black Sea Economic Studies, vol. 12-1, pp. $185-188$.

16. The Travel \& Tourism Competitiveness Report 2019 available at. http://www3.weforum.org/docs/WEF_TTCR_2019. pdf (accessed 12 November 2019).

17. The Travel \& Tourism Competitiveness Report 2017. available at. http://reports.weforum.org/travel-and-tourismcompetitiveness-report-2017/ (accessed 16 November 2019).

18. UNWTO (2018) “UNWTO Tourism Highlights, 2018 Edition", available at: https://www.eunwto.org/doi/ pdf/10.18111/9789284419876 (accessed 16 November 2019). 
Dzhhutashvili Nataliia

Kharkiv State University of Food Technology and Trade; Kyiv State College of Tourism and Hospitality

\section{INFLUENCE OF INBOUND TOURIST FLOW ON THE DEVELOPMENT OF THE HOSPITALITY SERVICE IN UKRAINE}

The hospitality industry, as an integral and important component of tourism, is gaining increasing socio-economic importance. It is a key component of the tourist product, as the level of service in the hospitality industry is one of the key factors for travelers' satisfaction. The purpose of the article is to identify current trends and the impact of inbound tourist flows on the development of the hospitality industry in Ukraine. The methods of content analysis, statistical and logical analysis have been used in the research process. Reduced flows of foreign nationals entering Ukraine in 2010-2017 have been identified. Only 38000 people, or 0.27\% of the number of foreign nationals who came to Ukraine in 2017, visited Ukraine for tourism, which is $96.4 \%$ less than in 2010. As a result, foreigners' demand for the hospitality services, which are mostly used by domestic consumers, is falling. In Ukraine, the outbound tourism is much higher than inbound, both in terms of number of travelers and in terms of cost. It is proved that the objective reasons for the decrease in inbound flows are the unfavorable security image of the country, as well as the low level of tourist competitiveness of Ukraine, accordingly, the domestic hotel industry is poorly realizing its potential. In such a situation, threats to the functioning and development of domains of the hospitality industry are increasing. The choice of accommodation for a temporary stay while in a foreign country depends to some extent on the purpose of the trip. For each category of visitors the different requirements, needs, expectations for the service product of the hotel are set. The necessity of their research and consideration during the transition to the management of hotel activity on the principle of client-orientation is shown. To this end, the search for adequate methods of market segmentation and differentiation of the hotel service product depending on the characteristics of the target audience is actualized. It is revealed that the most difficult problem of domestic hotels is the non-conformity of the level of service to the world standards, which is in some way due to the outdated material facilities and low staff qualification. The necessity of application of world experience and practice of service management, which will increase the attractiveness of hotels for guests, is indicated. It is suggested to manage the service in the hospitality industry on the principles of the consumer value chain and to use the service product circle of the hospitality industry for this purpose. The composition of the service product includes such components as material and technical facilities, staff, process, principles and rules of hospitality. The proposed approach combines quality of service standards with the expectations and impressions of the hotel customer.

Key words: hospitality industry, service product, tourism, tourist competitiveness, service product circle.

JEL classification: M31, F23, L10. 